\title{
Informational Effect of Stock Liquidity on Dividend Payouts: Evidence from Indonesia, 2008-2017
}

\author{
Alya Faradisi, Maria Ulpah ${ }^{*}$ \\ Department of Management, Universitas Indonesia, Depok, Indonesia \\ *Corresponding author. Email: mariaulpah@gmail.com
}

\begin{abstract}
This research investigates the informational effect of stock liquidity on dividend payouts in Indonesia from 2008 to 2017. Three dividend payout proxies are used: DVE (cash dividend scaled by earnings), DVC (cash dividend scaled by net operating cash flow), and DVP (the propensity for a dividend use dummy variable). Stock liquidity is measured using the Amihud Method. The results of this research indicate that a positive and significant relationship exists between stock liquidity and dividend payouts. This study used the generalized least square panel data method and logistic estimation method. Indications exist of an increase in the informational effect of stock liquidity on increasing dividend payouts. These results are consistent with the dynamic panel data estimation model.
\end{abstract}

Keywords: Stock liquidity, controlling shareholder, dividend payouts, informational effect, Indonesia

\section{INTRODUCTION}

When determining dividend payments in Indonesia, the factors that need to be considered are a company's current and expected future incomes. Company managers understand that the effect of dividends on stock prices and shareholder needs is increasing in importance at this time (Baker and Powell, 2012). In general, company managers use company cash flows after profitable investments to pay dividends (Baker and Powell, 2012). Several previous studies related to this research discussed how companies make dividend payment decisions considering the agency problems in emerging markets in Indonesia. As found in La Porta et al. (2000b), conflicts of agent interests can occur among the parties at a company, such as managers, controlling shareholders, and minority shareholders. Banarjee et al. (2007) stated that companies with greater and more profitable growth pay dividends, whereas higher growth companies prefer to make dividend payments. In this study, the relationship between stock liquidity and dividend payments is tested, assuming that liquidity is more relevant for corporate dividend decisions to pay higher dividends. However, for a small but high growth company without profits, market liquidity may not be profitable regarding the company's dividend policy-a statement that ignores the effect of stock liquidity information on dividend payment policies. Liquidity can reduce asymmetric information between insiders and outsiders by producing more information. Liquidity is considered to represent standard information on trade and can assist informed parties in disguising personal information that is not reflected in prices (Kyle, 1984). The degree of liquidity can be estimated using the return of absolute shares on the volume of trade, reflecting the price impact when liquidity has a positive and significant effect on expected returns (Amihud, 2002). Coval and Moskowitz (1999) found that asymmetric information (liquidity) can drive observed preferences for the geographically closest company.

Empirical theory shows that dividend payment rates and dividend value relevance are supported by information asymmetry related to existing assets and financial reporting quality (Hand and Landsman, 2005; Jensen, 1986; Koo et al., 2017; Myers and Majluf, 1984; Rees, 1997). Recording financial statements based on International Financial Reporting Standards can serve to reduce information asymmetry and improve the company's financial performance (Harakeh, Lee, and Walker, 2018). A better financial information environment is expected to reduce the free cash flow problem and unfavorable project development, which encourages managers to pay more dividends than to take over investor wealth (Jensen, 1986).

The case study company on the Indonesia Stock Exchange was selected because researchers from Indonesia and Indonesian companies have unique 
characteristics, such as high ownership concentration, state influence, and politically affected business relations. Little research exists that investigates the managers of businesses on the Indonesia Stock Exchange (IDX) who make decisions to pay dividends in the Indonesian corporate environment. Indonesian companies listed on the IDX determine dividend policies, and Indonesian company dividend policies depend on explicit policies developed by management in accordance with disclosures in a company's annual report. Changing this policy may have implications for all shareholders. For majority shareholders who have control over company managers, this policy provides potential benefits by maintaining the income that can be used to buy back shares and, subsequently, improve their control over a company. Conversely, minority shareholders may interpret policies as taking over their rights to receive cash dividends. In Indonesia, dividends are distributed in accordance with agreement among the company's shareholders at the General Meeting of Shareholders and the provisions stipulated in UU No. 40 of 2007 .

\section{THEORETICAL REVIEW}

\subsection{Payout Policy}

A payout policy addresses how companies provide returns on the capital that investors provide to companies. Payments can take the form of dividends or share repurchases. Modern research related to dividend policy was first initiated and rooted in the concepts of Miller and Modigliani (1961). They wrote down their thoughts in a research article entitled Dividend Policy, Growth, and the Value of Shares (1961) regarding irrelevance propositions. The article explained the conditions in which the method or patterns that a company uses to determine a dividend payment policy are not relevant to determining its value. However, in the real world, the company's payout policy seeks to follow a systemic and structured pattern. A payout policy that can be predicted can respond to changes in company value. Lintner (1956) found a number of interesting related payout policies and shaped them into several stylized facts regarding dividend policy. First, dividends are "sticky," indicating that dividends tend to remain unchanged as company earnings increase and decrease. Second, the dividend level is related to sustainable long-term earnings. Third, dividends tend to be "smooth" from year to year, which is intended to lead to a target long-term payout ratio.

\subsection{Dividend Irrelevance Theory}

The dividend irrelevance theory of Miller and Modigliani (1961) states that, in a perfect market, the dividend payment policy is less relevant to determining a company's value. The basis of their research was the investment policy used to determine a company's value. Payouts to shareholders are the proceeds that remain between income and investments. The dividend payment policy is considered irrelevant to the investor because the pattern of dividend payments can be replicated using the appropriate form of buying and selling equity. Investors are also assumed to be able to create "homemade dividends," through which they do not want to pay more for the company given certain dividend payment policies. This theory assumes that financial markets are perfect, exhibit rational market behavior, and reflect full shareholder certainty through the development of their dividend policy by buying and selling shares.

Paying dividends when the company's internal cash flow is insufficient to fund all investments does not increase the company's owner's wealth. In contrast, this situation requires the company to resell additional securities and equity. Given ideal terms, new funding can occur because an increase in dividends today results in the company being obligated to increase external funding to cover dividend payments. Thus, the dividend policy is irrelevant in measuring firm value in an efficient market, according to the assumptions of Miller and Modigliani (1961).

\subsection{Agency Theory}

In general, companies have the goal of helping shareholders prosper (Friedman, cited in Pfarrer, 2010). To achieve this objective, several parties have different responsibilities, such as managers whose performance is assessed by their ability to run the company and create corporate value. In agency theory, the company's manager plays the role of an agent who runs the company to achieve its mission. The second partyshareholders or investors-represent the parties that invest additional funds in the company. In agency theory, the investor's role is as a principal (Jensen and Meckling, 1976).

Agency theory regulates the relationship between managers and shareholders in a work contract, and they must work together to create corporate value (Jensen and Meckling, 1976). Principals and agents have the same characteristics as utility maximizers for their interests. Shareholders trust managers to increase the company's value and manage the company effectively and efficiently. Managers maximize the company's value for their benefit by utilizing free cash flows to invest in projects with negative NPV values and to satisfy their interests (Jensen, 1986). Meanwhile, shareholders ask managers to maximize the company's value and utilize free cash flows as dividendsincentives that will be accepted by shareholders. Ultimately, managers are required to maximize the welfare of shareholders (investors). This difference in interests represents the agency problem. 


\subsection{Liquidity}

According to Haris (2003), the perfect market condition is when the securities market can be converted into cash and vice versa in unlimited amounts without requiring instant costs. Liquidity represents the ability to engage in large and fast transactions at low costs (Haris, 2003). In addition to the concept of liquidity by Haris (2003), the findings from Aitken and Comerton-Forde (2003) are related to the management of liquidity, which can be done through two trade-based approaches. The first approach to calculate liquidity uses data sourced from ex post transactions, such as trading volume, trading value, turnover ratio, number of traders, and order-based measures. The second approach measures the bid-ask spread and is related to data from transaction orders.

In this study, the researchers use the trade-based measure liquidity approach - the Amihud method. This method was selected because the researchers want to observe the effects of stock liquidity information. This method is appropriate because it reveals price impacts. Several companies used as research samples have intraday data with high trading frequency. According to Amihud (2002), liquidity can be calculated using daily returns and Rupiah daily volume traded, as in the following formula:

$$
\text { Amihudi,m }=\frac{1}{N \mathrm{i}, \mathrm{m}} \sum_{t=1}^{N \mathrm{i}, \mathrm{m}} \frac{|R \mathrm{i}, \mathrm{t}, \mathrm{m}|}{\operatorname{Vol} i, t, m}
$$

Amihud's method of calculating stock liquidity has limitations, such as inaccurate results for a company with zero daily trading volume. This condition often occurs on the IDX primarily because of highly illiquid market conditions. Such conditions can also occur if an IDX policy temporarily stops trading or suspends trading for a period. The suspension usually occurs because a company committed a violation. According to Amihud (2002), this method is very appropriate for observing price impacts in the market. We can obtain a value that describes the price changes that occur from large transactions on a particular day by calculating the value of the Rupiah originating from daily transactions that have returns on that day. The smaller the value of the Amihud calculation, the better the liquidity of a company's stock because the stock is able to carry out large transactions without causing dramatic price changes.

\subsection{Stock Liquidity and Dividend Payouts}

Miller and Modigliani (1961) stated that the proportion of dividends that are irrelevant in a perfect market assuming shareholder wealth is only determined by the company's investment opportunities and does not depend on dividend payment policies. However, the fact is that stock liquidity allows investors who need cash to create homemade dividends by selling their ownership amounts at no cost. The implication is that companies with more liquid stocks pay lower dividends. Banarjee et al. (2007) found that stocks of less liquid companies tend to pay more in cash dividends, which supports the view that stock market liquidity is a substitute for dividends. Stock liquidity can reduce information asymmetry between insiders and outsiders by producing more information. Using information on trade standards, liquidity can provide information that is not reflected in prices (Kyle, 1984). In general, some studies concluded that insider information is more complete than that of outsiders, but we cannot eliminate the possibility that outsiders can obtain information that is not owned by insiders. Typically, companies employ consultants to analyze existing information for corporate decision making when conducting investigations.

Regarding the importance of personal information in stock prices as a determinant of a dividend policy, Jiang, Ma, and Shi (2017) showed a positive relationship between stock liquidity and dividend payments. In their research, they expressed the opinion that higher stock liquidity allows investors to conduct transactions using their personal information and absorb more information on the actions of controlling shareholders as observed from the stock price. Thus, controlling shareholders pay more dividends. Banarjee et al. (2007) found the strength of the empirical relationship between a company's dividend policy and stock liquidity by controlling the company's ability to pay dividends. Fewer dividend payments periods are characterized by lower trade costs and increased market activity. In addition, Banarjee et al. (2007) found that companies with less liquid stocks may continue to pay dividends.

\subsection{Hypothesis}

Based on a theoretical review and prior research, the following research hypothesis identifies the research objectives to be achieved.

Hypothesis 1a: The information effect of stock liquidity is significant on dividend payouts in Indonesia.

\section{RESEARCH DESIGN}

\section{Sample and Data}

This study uses unbalanced panel data from companies listed on the IDX from 2008 to 2017. The selected sample includes only non-financial firms because of the differences in leverage and excludes nonutilities firms because of the strong regulations in the sector. Based on these criteria, 258 sample companies were obtained. 


\section{Research Framework and Model}

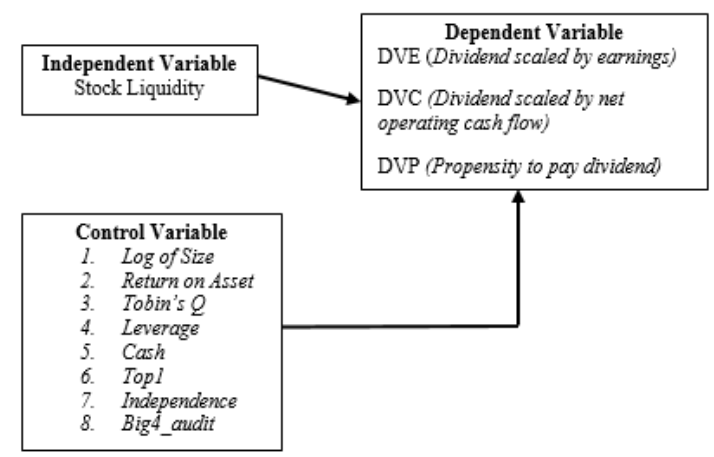

Figure I. Research Frame and Model

In this study, three models are tested using the different cash dividend proxies, as follows:

$D V E_{i t}=\alpha_{0}+\beta_{1}$ Liquidity $_{i t}+\Sigma_{k} \gamma_{k}$ Controls $_{i t}^{k}+\varepsilon_{i t}$

$D V C_{i t}=\alpha_{0}+\beta_{1}$ Liquidity $_{i t}+\Sigma_{k} \gamma_{k}$ Controls $_{i t}^{k}+\varepsilon_{i t}$

$P\left(D V P_{i t}=1 \mid X\right)=\alpha_{0}+\beta_{1}$ Liquidity $_{i t}+\Sigma_{k} \gamma_{k}$ Controls $_{i t}^{k}+$ $\varepsilon_{i t} \quad(4)$

To process the data, researchers used unbalanced panel data regression methods with fixed effect models and logistic estimation methods.

\section{RESULTS AND DISCUSSION}

\subsection{Analysis of Statistics Descriptive}

The purpose of this study is to analyze the information effect of stock liquidity on dividend payments using three dividend proxies. The samples used in the study were 258 companies listed on the IDX from 2008 to 2017, unbalanced panel data, and a total of 2,155 observations. The results of the descriptive statistics of the research variables are as follows.
Table I. Descriptive Statistics

\begin{tabular}{|l|r|r|r|r|}
\hline Variable & \multicolumn{1}{l|}{ Mean } & \multicolumn{1}{l|}{ Std. Dev } & \multicolumn{1}{l|}{ Min } & \multicolumn{1}{l|}{ Max } \\
\hline DVE & 12.502 & 21.170 & 0 & 99.92 \\
\hline DVC & 11.325 & 21.620 & 0 & 137.68 \\
\hline DVP & 0.3868 & 0.487 & 0 & 1 \\
\hline Ln(liquidity) & -1.306 & 1.547 & -6.547 & 0 \\
\hline Firm Size & 21.105 & 1.799 & 14.935 & 28.292 \\
\hline ROA & 3.483 & 13.875 & -172.305 & 134.743 \\
\hline Tobin's Q & 1.743 & 2.643 & 0.0013 & 38.29 \\
\hline Ln(leverage) & -0.903 & 0.869 & -8.33 & 5.10 \\
\hline Cash & 14.977 & 50.042 & 0.0007 & 896.3 \\
\hline Top1 & 49.329 & 23.06 & 0.14 & 99.88 \\
\hline Independence & 8.135 & 12.962 & 0 & 66.67 \\
\hline Big4 Audit & 0.340 & 0.474 & 0 & 1 \\
\hline No. Obs. & 2155 & & & \\
\hline Sample & 258 & & & \\
\hline
\end{tabular}

The researcher uses a generalized least square model because of a violation of the classified assumptions in the study, namely, heteroskedasticity when using a fixed effect model. The regression results for this research model indicate the information effect of stock liquidity on dividend payments to companies listed on the IDX from 2008 to 2017. 


\subsection{Regression Results}

Table II. Regression results

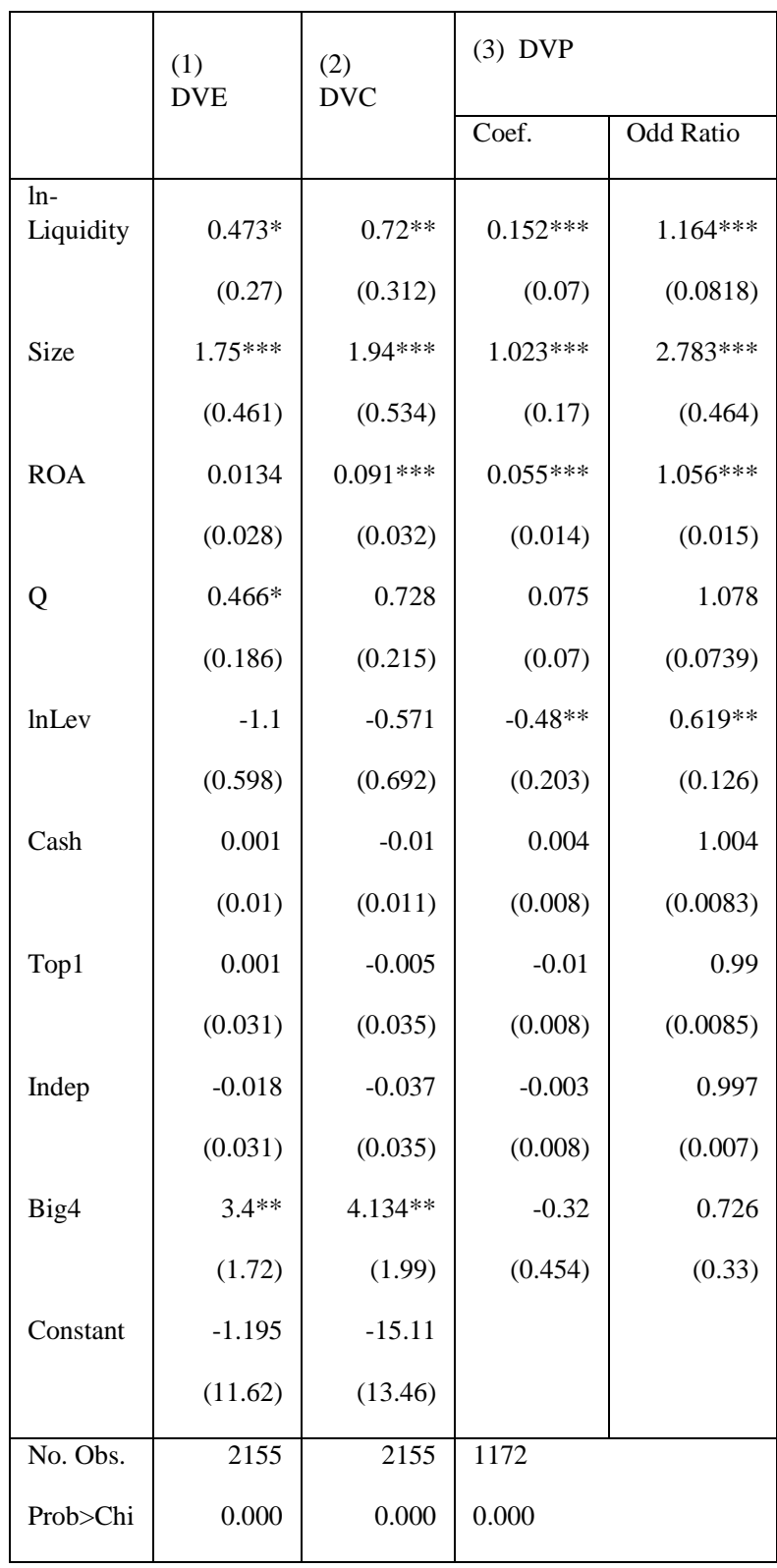

*Significant at $10 \%$

$* * *$ Significant at $5 \%$

$* * *$ Significant at $1 \%$

The test results for the model are consistent when three different dividend calculation proxies are used, which shows a significant positive effect at the $1 \%, 5 \%$, and $10 \%$ levels regarding the effect of stock liquidity information on the amount of dividend payments by companies listed on the IDX. In the third model that uses a dummy variable, the result is significant at the $1 \%$ level. The results of this test are in accordance with the research hypothesis that stock liquidity information has a positive effect on dividend payments, indicating that an increase in the liquidity of company shares can increase the dividend payments of registered companies in Indonesia. The results of this study are consistent with the hypothesis that the effect of information on stock liquidity positively influences the dividend payment amount (Jiang, Ma, and Shi, 2017). This study found that higher stock liquidity allows investors to conduct transactions with personal and public information, as observed in stock prices, thus making controlling shareholders pay more dividends.

Amedo and Winifred (2015) found that the importance of stock liquidity information determines dividend policy. Because every change in company policy can trigger a market reaction, company managers must be more sensitive to market reactions. Jiang, Ma, and Shi (2017) showed that stock liquidity can prevent information asymmetry between minority and controlling shareholders to increase dividend payments. This phenomenon can occur because the effect of stock liquidity information can reduce the tendency of controlling shareholders to take over and increase their incentives to pay more dividends.

The test results of the influence of each control variable on the dependent variable with three different dividend proxies also produce different influences and relationships for each regression model. In this study, a robustness test was conducted to test the strength of the regression results of the research model using alternative liquidity calculations. The researcher divides the stock liquidity group into high liquidity and low liquidity based on the average stock liquidity value for the three proxy dividend payments. The robustness test results indicate that this research is robust because the significance of and direction between the stock's variable liquidity toward dividend payments do not change for the three different dividend calculation proxies.

\subsection{Robustness Test}

A robustness test was conducted to test the strength of the regression results of the research model using alternative liquidity calculations. The researcher divided the stock liquidity group into high liquidity and low liquidity based on the average stock liquidity value for the three proxy dividend payments. The robustness test results indicate that this research is robust because the significance of and direction between the variable liquidity of the stock toward dividend payments do not change for the three different dividend calculation proxies. 
Table III. Robustness test (Low liquidity)

\begin{tabular}{|c|c|c|c|c|}
\hline & \multirow{2}{*}{$\begin{array}{l}\text { (1) } \\
\text { DVE }\end{array}$} & \multirow{2}{*}{$\begin{array}{l}\text { (2) } \\
\text { DVC }\end{array}$} & \multicolumn{2}{|l|}{ (3) DVP } \\
\hline & & & Coef. & Odd Ratio \\
\hline \multirow[t]{2}{*}{ InLiquidity } & $0.356^{*}$ & $0.755^{*}$ & $0.257 *$ & $1.29 *$ \\
\hline & $(0.399)$ & $(0.391)$ & (0.149) & (0.193) \\
\hline \multirow[t]{2}{*}{ Size } & $1.65^{* *}$ & 0.435 & $3.437 * * *$ & $31.093 * * *$ \\
\hline & $(0.77)$ & $(0.752)$ & $(0.69)$ & $(21.47)$ \\
\hline \multirow[t]{2}{*}{ ROA } & -0.037 & 0.025 & 0.03 & 1.03 \\
\hline & $(0.042)$ & $(0.041)$ & $(0.034)$ & $(0.035)$ \\
\hline \multirow[t]{2}{*}{ Tobin's Q } & $0.932 * *$ & $0.967 * *$ & 0.292 & 1.33 \\
\hline & $(0.45)$ & $(0.442)$ & $(0.495)$ & $(0.663)$ \\
\hline \multirow[t]{2}{*}{ lnLeverage } & 0.093 & -0.292 & -0.379 & 0.684 \\
\hline & $(0.802)$ & $(0.785)$ & $(0.418)$ & $(0.286)$ \\
\hline \multirow[t]{2}{*}{ Cash } & 0.001 & -0.003 & -0.00471 & 0.995 \\
\hline & $(0.008)$ & $(0.008)$ & $(0.008)$ & $(0.008)$ \\
\hline \multirow[t]{2}{*}{ Top1 } & -0.013 & 0.0245 & $-0.037 * *$ & $0.964 * *$ \\
\hline & $(0.042)$ & $(0.04)$ & $(0.018)$ & $(0.017)$ \\
\hline \multirow[t]{2}{*}{ Independence } & -0.037 & -0.022 & $-0.035 * *$ & $0.965 * *$ \\
\hline & $(0.04)$ & $(0.039)$ & $(0.016)$ & $(0.015)$ \\
\hline \multirow[t]{2}{*}{ Big 4 Audit } & 0.087 & $7.486 * *$ & 0.49 & 1.632 \\
\hline & (3.184) & (3.117) & (1.03) & (1.679) \\
\hline \multirow[t]{2}{*}{ Constant } & -32.22 & -9.79 & & \\
\hline & (15.82) & (15.49) & & \\
\hline No. Obs. & 840 & 840 & \multicolumn{2}{|l|}{316} \\
\hline Prob $>$ Chi & 0.000 & 0.000 & \multicolumn{2}{|l|}{0.000} \\
\hline
\end{tabular}

*Significant at $10 \%$

$* * *$ Significant at $5 \%$

$* * *$ Significant at $1 \%$
Table IV. Robustness test (high liquidity)

\begin{tabular}{|c|c|c|c|c|}
\hline & (1) & (2) & (3) DVP & \\
\hline & & & Coef. & $\begin{array}{l}\text { Odd } \\
\text { Ratio }\end{array}$ \\
\hline lnLiquidity & $4.69^{* * * *}$ & $6.550^{\text {*** }}$ & $0.95^{* * *}$ & $2.593 * * *$ \\
\hline & 1.39 & (1.67) & $(0.364)$ & (0.944) \\
\hline Size & $1.22 * *$ & $1.897 * *$ & $0.658 * * *$ & $1.93 * * *$ \\
\hline & 0.605 & $(0.728)$ & (0.174) & $(0.336)$ \\
\hline ROA & 0.018 & $0.133 * *$ & $0.05^{* * *}$ & $1.050 * * *$ \\
\hline & 0.041 & $(0.05)$ & $(0.018)$ & $(0.0192)$ \\
\hline Tobin's Q & 0.301 & $0.714 * *$ & 0.02 & 1.021 \\
\hline & 0.223 & $(0.268)$ & (0.077) & $(0.0789)$ \\
\hline lnLeverage & $-2.22 * *$ & -1.766 & $-0.665 * *$ & $0.5142 * *$ \\
\hline & 0.91 & (1.094) & $(0.306)$ & $(0.157)$ \\
\hline Cash & -0.019 & $-0.211 * * *$ & $0.035^{* *}$ & $1.035^{* *}$ \\
\hline & $(0.055)$ & $(0.066)$ & $(0.016)$ & $(0.0167)$ \\
\hline Top1 & 0.041 & 0.027 & 0.0003 & 1.000 \\
\hline & $(0.046)$ & $(0.055)$ & (0.0128) & (0.0128) \\
\hline Independence & 0.016 & -0.0097 & 0.006 & 1.006 \\
\hline & $(0.046)$ & $(0.056)$ & $(0.0104)$ & $(0.01)$ \\
\hline Big 4 Audit & 2.76 & 0.612 & -0.62 & 0.537 \\
\hline & (2.19) & (2.64) & $(0.578)$ & $(0.311)$ \\
\hline Constant & 7.22 & -14.42 & & \\
\hline & (14.89) & (17.91) & & \\
\hline No. Obs. & 1315 & 1315 & 685 & \\
\hline Prob $>$ Chi & 0.000 & 0.000 & 0.000 & \\
\hline
\end{tabular}

*Significant at $10 \%$

***Significant at $5 \%$

$* * *$ Significant at $1 \%$

Changes in the estimation model are made by dividing the stock liquidity variable into two groupshigh liquidity and low liquidity. The robustness test results indicate that this research is robust because the significance of and direction between the stock's variable liquidity toward dividend payments do not change for the three different dividend calculation proxies. 


\section{CONCLUSIONS AND SUGGESTIONS}

\subsection{Conclusions}

The test of the research hypothesis indicates that a significant positive effect exists of stock liquidity information on dividend payments, which means that an increase in stock liquidity can increase the dividend payments of registered companies in Indonesia. These results are in accordance with the reference articles (Jiang, Ma, and Shi, 2017). The results of this study indicate that companies with high stock liquidity have high dividend payments and tend to increase dividend payments compared with companies with low stock liquidity. The regression model was tested by dividing the liquidity group into high and low stock liquidity. The results of testing the two groups were consistent with the results of the tests using all of the samples. This study proved that liquidity can reduce the information asymmetry between insiders and outsiders by generating more information. Understanding the positive impact of stock liquidity on dividend payments can determine the appropriate policy for reducing information asymmetry in the market by developing policies related to minimizing the company's trading volume to ensure that the company's shares remain liquid and the company's dividend payments can be increased.

\section{REFERENCES}

[1] Amadeo, K. (2019). Foreign direct investment: Definition, example, pros, cons. The Balance, 25 June 2019, https://www.thebalance.com/foreigndirect-investment-fdi-pros-cons-and-importance3306283.

[2] Aitken, M., Comerton-Forde, C. (2003). How should liquidity be measured. Pacific-basin Finance Journal, 11, 45-49.

[3] Allen, F., Michaely, R. (2003). Payout policy. Handbook of the Economics of Finance, 1, 337429.

[4] De Cesari, A., Huang-Meier, W. (2015). Dividend changes and stock price informativeness. Journal of Corporate Finance, 35, 1-17.

[5] Amihud, Y. (2002). Illiquidity and Stock returns: Cross-section and time-series effects. Journal of Financial Markets, 5, 31-56.

[6] Banerjee, S., Gatchev, V.A., Spindt, P.A., 2007. Stock market liquidity and firm dividend policy. Journal of Financial and Quantitative Analysis 42(2), 369-397.

[7] Chang, B.K., Kang, E., Li, Y. (2014). The impact of institutional ownership on dividends - An agency theory based analysis, 1-31.
[8] Claessens, S., Djankov, S., Fan, J.P.H., Lang, L.H.P. (2002). Disentangling the incentive and entrenchment effects of large shareholdings, $\operatorname{LVII}(6)$.

[9] Fama, E., French, K. (2001). Disappearing dividends: Changing firm characteristics or lower propensity to pay. Journal of Financial Economics, $60,3-43$

[10] Jiang, F., Ma, Y., Shi, B. (2017). Stock liquidity and dividend payouts. Journal of Corporate Finance, 42, 295-314.

[11] Goyal, A., Muckley, C. (2013). Cash dividends and investor protection in Asia. International Review of Financial Analysis29, 31-43.

[12] Baker, H.K., Powell, G.E. (2012). Dividend policy in Indonesia: survey evidence from executives, Journal of Asia Business Studies, 6, 79-92.

[13] Baker, H.K., Weigand, R. (2015). Corporate dividend policy revisited. Managerial Finance, 41, 126-144.

[14] Hand, J., Landsman, W. (2005). The pricing of dividends in equity valuation. Journal of Business Finance \& Accounting, 32, 435-469.

[15] Harris, L.E. (2003). Trading and exchanges: Market microstructure for practitioners. New York: Oxford University Press.

[16] Jensen, M. (1986). Agency costs of free cash flow, corporate finance, and takeovers. American Economic Review, 76, 323-329.

[17] Coval, D.J., Moskowitz, T.J. (1999). The Journal of Finance, 54, 2045-2073 Published by: Wiley for the American Finance Association.

[18] Koo, D., Ramalingegowda, S., Yu, Y. (2017). The effect of financial reporting quality on corporate dividend policy. Review of Accounting Studies, 22, 753-790.

[19] Kyle, A. (1984). Market structure, information, futures markets, and price formation. In: Storey, G.G., Schmitz, A., Sarris, A. (Eds.), International Agricultural Trade: Advanced Readings in Price Formation, Market Structure and Price Instability. Westview Press, Boulder, CO, pp. 45-64.

[20] La Porta, R., Lopez-de-Silanes, F., Shleifer, A., Vishny, R. (2000b). Investor protection and corporate governance. Journal of Financial Economics, 58(1), 3-27.

[21] Lintner, I. (1956). Distribution of income of corporation among dividends, retained earning, and taxes. The American Economics Review, 97-113. 
[22] López, F.J., Crisóstomo, V.L., Emerging, S., Finance, M., May-june, N., Iturriaga, F.J.L., Lima, V. (2018). Do leverage, dividend payout, and ownership concentration influence firms value creation? 46(3), 80-94.

[23] Miller, M.H. and Rock, K. (1985). Dividend policy under asymmetric information. Journal of Finance, 40, 1031-1051.

[24] Miller, M.H., Modigliani, F. (1961). Dividend policy, growth, and the valuation of shares. Journal of Business 34(4), 411-433.

[25] Harakeh, M., Lee, E., Walker, M. (2019).The effect of information shocks on dividend payout and dividend value relevance. International Review of Financial Analysis, 61, 82-96.

[26] Myers, S., Majluf, N. (1984). Corporate financing and investment decisions when firms have information that investors do not have. Journal of Financial Economics, 12, 187-221.
[27] Pfarrer, M.D. (2010). What is the purpose of the firm?: Shareholder and stakeholder theories. Good Business: Exercising Effective and Ethical Leadership, 86-93.

[28] Porta, R. La, Lopez-de-Silanes, F., Shleifer, A., Vishny, R. (1997). Investor protection and corporate governance. Journal of Finance, 52(2), 737-783.

[29] Rees, W. (1997). The impact of dividends, debt and investment on valuation model. Journal of Business Finance \& Accounting, 24, 11-40.

[30] Setia-Atmaja, L., Tanewski, G.A., Skully, M. (2009). The role of dividends, debt and board structure in the governance of family controlled firms. Journal of Business Finance and Accounting, 36(7-8), 863-898.

[31] Corwin SA, Schultz P. (2012). A simple way to estimate bid-ask spreads from daily high and low prices. The Journal of Finance, 67, 719-759. 